\title{
Six years of cover performance data for leading practice store and release cover trials at Century Mine
}

\author{
PL Defferrard New Century Resources Limited, Australia \\ TK Rohde SGM Environmental Pty Limited, Australia
}

\begin{abstract}
A store and release cover is designed to minimise potential contamination from acid forming tailings which is site specific; being a function, among other factors, of the borrow materials available, tailings deposition method, and the climatic setting. Three experimental cover trials, each $75 \mathrm{~m}$ by $75 \mathrm{~m}$ square have been developed and constructed on the tailings storage facility at New Century Resources Century Mine in the semi- arid North West Queensland.

In settings such as Century Mine, store and release cover systems rely on the storage of rainfall during the wet season and its release during the dry season through evapotranspiration. They typically comprise a compacted fine-grained reduced permeability layer (RPL) of compacted clay overlain by a significant thickness of loose rock and soil mulch. Where there is a paucity of fine-grained material for the RPL it may be possible to engineer a material from a mixture of coarse and fined grained material.

The cover trials have been designed to test three potential engineered RPLs which include minus $10 \mathrm{~mm}$ crusher dust conditioned with bentonite, a geosynthetic clay liner placed between an upper and lower layer of minus $10 \mathrm{~mm}$ crusher dust, and minus $10 \mathrm{~mm}$ crusher dust conditioned with an extra 15 to $30 \%$ fines (passing $0.075 \mathrm{~mm}$ ).

All three cover trials have been enhanced by the addition of a capillary break layer directly above the tailings. The purpose of the capillary break is to stop the vertical rise of potential contamination from the acid forming tailings (metals and salts) back into the loose rock and soil mulch layer of the cover.

The performance of the cover trials has been monitored by instrumentation including volumetric water content and matric suction sensors, a weather station capable of estimating evapotranspiration and lysimeters to measure percolation (deep infiltration) through the base of the cover. The instrumentation allows for direct measurement of infiltration into the cover, storage of rainfall, percolation through the base of the cover and in situ soil water characteristic curves for predictive modelling.

This paper describes the store and release cover trials construction at Century Mine, the instrumentation of the trial covers and the cover performance monitoring data collected over the past six years.

Keywords: Century Mine, store and release cover, instrumentation, cover performance, tailings storage facility

\section{Introduction}

New Century Resources (NCR) Century Mine over the past 18 months has transitioned from a care and maintenance phase into a progressive economic rehabilitation tailings reprocessing operation, whereby the tailings ( $79 \mathrm{Mt}$ ) are hydraulically mined, zinc recovered through retreatment and the tailings sub aqueously deposited into the pit. The tailings retreatment and in-pit disposal process will achieve a significant reduction in the overall closure liability associated with the tailings storage facility (TSF). Even though an engineered cover option will not form the main TSF closure strategy for the site, the information obtained from the cover trials will provide valuable insight into the best cover system, in the event any residual contaminated materials such as regulated landfills may need to be encapsulated.
\end{abstract}




\subsection{Site location}

The mine is located at Lawn Hill, $250 \mathrm{~km}$ northwest of Mount Isa in the semi-arid Lower Gulf and processes zinc concentrate at Lawn Hill. Zinc concentrate is transferred as a slurry $304 \mathrm{~km}$ by an underground pipeline to the Port facility at Karumba for shipping to smelters in Australia, Europe, and Asia.

\section{$1.2 \quad$ Climate}

The average rainfall is $544 \mathrm{~mm}$, with a distinct wet and dry season. The wet season extends from November to early April and accounts for $90 \%$ of annual rainfall. Evaporation dominates the climate with a ratio of evaporation and transpiration (evapotranspiration) to rainfall of about 4:1.

Store and release cover systems (covers) are recommended for the long-term management of mineralised wastes in climate regions such as Century (International Network for Acid Prevention [INAP] 2009) where evapotranspiration dominates.

\section{$2 \quad$ Background}

\subsection{Tailings storage facility}

Since commissioning in 1999, approximately 79 Mt of tailings has been deposited into the TSF. The TSF has been operated as a single point down-valley discharge with the main embankment $3 \mathrm{~km}$ south of the discharge point. Two decants are located on the main embankment which direct supernatant into the downstream evaporation dam. The total tailings beach area of the TSF at the commencement of hydraulic mining was approximately 360 ha.

\subsubsection{Tailings storage facility closure strategy}

The closure strategy for the tailings dam is based on a progressive economic rehabilitation model whereby the tailings are removed by hydraulic cannons and some mechanical assistance, followed by ripping and seeding with provenance species of the disturbance footprint. The TSF cover trial performance data will inform residual contamination material encapsulation designs if required.

\subsubsection{Tailings storage facility acid base accounting}

It is understood that

"The acid base accounting shows that the net acid producing potential of the tailings in the TSF is high (Department of Industry Tourism and Resources 2007), and that after 16 years of operation the TSF would still be expected to generate acid for several hundred years. The closure strategy needs to mitigate the pathway by which acid rock drainage (ARD) can reach the receiving environment. The potential pathway to the receiving environment is by percolation since this has the potential to flush the ARD oxidation products from the TSF." (Defferrard \& Rohde 2016, p. 3)

The acidity within the TSF could potentially produce sulphuric acid in the range 81.68-203.73 $\mathrm{kg} \mathrm{H}_{2} \mathrm{SO}_{4} / \mathrm{t}$ (Defferrard \& Rohde 2016).

\section{Tailings storage facility cover trial designs}

The cover trial design had to consider influences of climate, hydrology, human activities, vegetation, fauna/macro fauna (not discussed in this paper), settlement and constructability (INAP 2009). 


\subsection{Cover attributes}

Due to observed learnings and fatal flaws associated with the cover performance on the bulk sample tailings dam at Century Mine (Defferrard et al. 2014), as well as selecting the cover appropriate for the rainfall to evapotranspiration ratio as per the GARD Guide ${ }^{\mathrm{TM}}$ (INAP 2009), the following attributes for a TSF store and release cover were identified:

- Surface cover has to support local vegetation.

- The final surface should be hummocky in nature to facilitate infiltration and storage of rainfall.

- A reduced permeability layer (RPL) to significantly reduce percolation into the tailings mass.

- Oxygen flux into the tailings mass should be reduced with an RPL.

- A running layer for equipment to place the RPL.

- A capillary break (CB) has to be incorporated into the cover to prevent the potential transport of metals and salts through the cover to the surface.

- The cover should be not complex in nature to increase constructability and reduce costs.

Further model sensitivity analysis and cover refinement produced the final cover design which consisted of a cover $2.7 \mathrm{~m}$ in thickness including a $0.3 \mathrm{~m} \mathrm{CB}, 0.3 \mathrm{~m}$ compacted rock mulch running layer, $0.6 \mathrm{~m} \mathrm{RPL}$ and a $1.5 \mathrm{~m}$ uncompacted rock mulch layer. The southeast corner of each cover trial $(10 \mathrm{~m} \times 10 \mathrm{~m})$ was constructed without a CB to ascertain in a future sampling program if a capillary layer is essential (Figure 1). The RPL was the only component that differed between the three trials (Figure 2). Each of the cover trials is separated by compacted clay embankments (Figure 1).

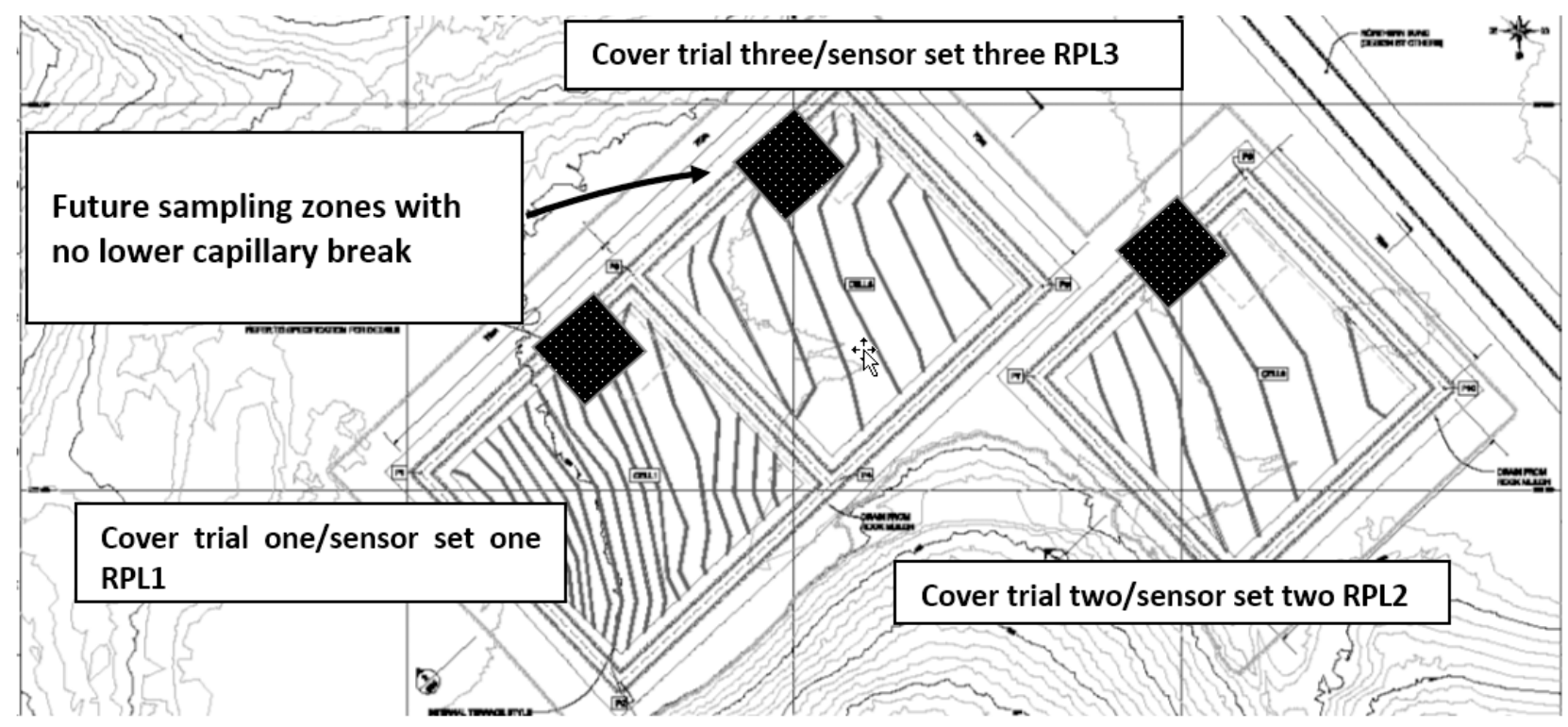

Figure 1 Plan view showing the three cover trials on the partitioned TSF upper beach and the section of the covers free of a capillary break layer, shown in shaded area 


\begin{tabular}{|c|c|c|}
\hline ROCK MULCH & $1.5 \mathrm{~m}$ & Uncompacted Rock Mulch \\
\hline REDUCED PERMEABILITY LAYER & $0.6 \mathrm{~m}$ & $-10 \mathrm{~mm}$ Cracker Dust Material with Minimum 30\% Fines \\
\hline COMPACTED ROCK MULCH & $0.3 \mathrm{~m}$ & Compacted Weathered Rock \\
\hline CAPILLARY BREAK & $0.3 \mathrm{~m}$ & "+10 mm" Sized Rock Mulch \\
\hline EXISTING TAILINGS & & \\
\hline
\end{tabular}

(a)

\begin{tabular}{|c|c|c|}
\hline ROCK MULCH & $1.5 \mathrm{~m}$ & Uncompacted Rock Mulch \\
\hline REDUCED PERMEABILITY LAYER & $0.6 \mathrm{~m}$ & $\begin{array}{l}-10 \mathrm{~mm} \text { Cracker Dust Material with Minimum } 15 \% \text { and } \\
\text { Maximum 30\% Fines plus } 10 \% \text { by dry weight of Bentonite }\end{array}$ \\
\hline COMPACTED ROCK MULCH & $0.3 \mathrm{~m}$ & Compacted Weathered Rock \\
\hline CAPILEARY BREAK & $0.3 \mathrm{~m}$ & "+10 mm" Sized Rock Mulch \\
\hline EXISTING TAILINGS & & \\
\hline
\end{tabular}

(b)

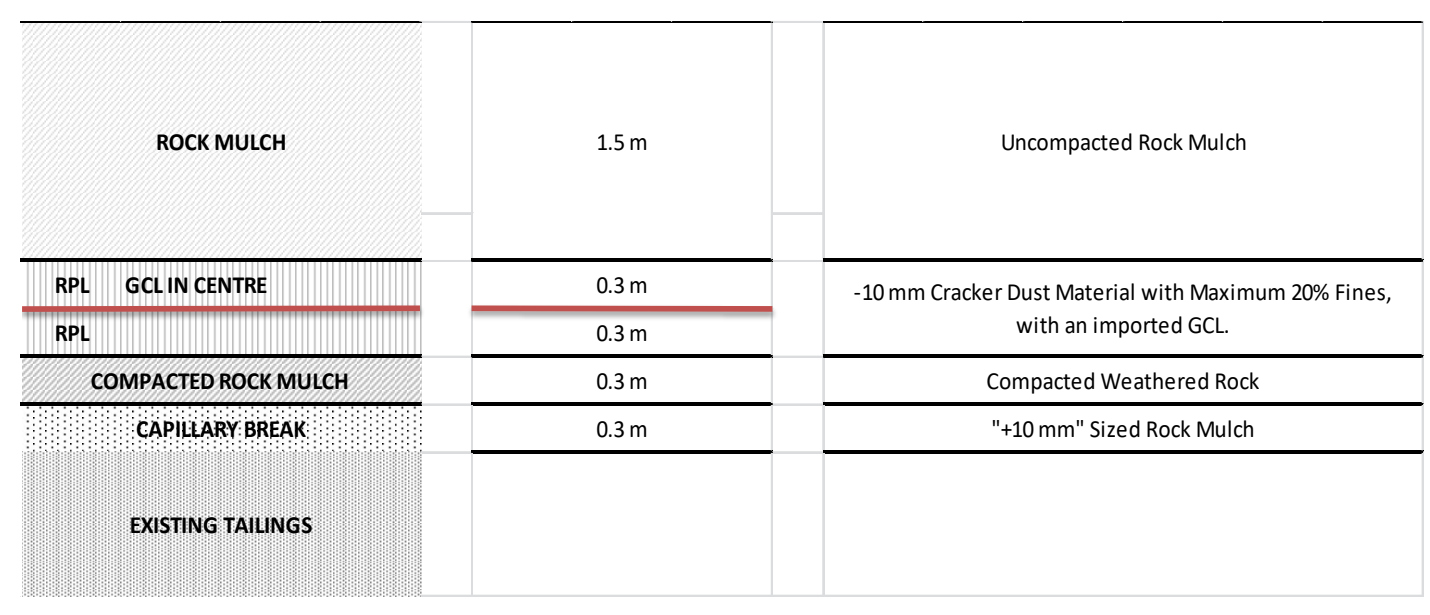

(c)

Figure 2 (a) RPL1 minus $10 \mathrm{~mm}$ with minimum $30 \%$ fines passing $0.075 \mathrm{~mm}$ sieve; (b) RPL2 minus $10 \mathrm{~mm}$ with $15-30 \%$ fines passing $0.075 \mathrm{~mm}$ sieve and $10 \%$ by dry weight of bentonite; (c) RPL3 minus $10 \mathrm{~mm}$ with maximum $20 \%$ fines passing $0.075 \mathrm{~mm}$ sieve and a sandwiched geosynthetic clay liner (GCL) 


\subsection{Material characterisation}

\subsubsection{Reduced permeability layer}

It was identified that:

"Suitable clays for the construction of RPL are a limited resource within the mining lease; however, natural clay deposits do exist in Gregory and Korong land systems as identified by Dames \& Moore (1994). Within these land systems the natural clay deposits are between approximately $0.4 \mathrm{~m}$ and $1.6 \mathrm{~m}$ thick. The required volume of RPL mixture to construct a sealing layer over the 360 ha TSF would be approximately $2.2 \mathrm{Mm}^{3}$. This would equate to a disturbance borrow area of approximately $180 \mathrm{ha}$, which could potentially create another closure liability as it would be challenging to restore it back to its former land system," (Defferrard \& Rohde 2016, p. 6)

"Large reserves of non-acid forming (NAF) dolomite mine waste was ruled out for manufacturing the RPL due to the large haul distance $(11 \mathrm{~km})$ to the TSF as well as the risk of saturated permeability ( $\left.K_{\text {sat }}\right)$ degradation through calcium and magnesium exchange with bentonite products within RPL2 and RPL3 (Buckley et al. 2010)." (Defferrard \& Rohde 2016, p. 6)

To achieve the cover attribute of constructability the RPL mixture was sourced from natural ridge material from the Termite ranges (siltstone, sandstone and shale) where the TSF was built to produce $-10 \mathrm{~mm}$ mixture, through a crushing and screening process. The average field $\mathrm{K}_{\text {sat }}$ for this material with $30 \%$ fines passing $0.075 \mathrm{~mm}$ was $2.0 \times 10^{-9} \mathrm{~m} / \mathrm{s}$ which is comparable to natural clay deposits. The disturbance footprint for this material would be less than $25 \%$ of the disturbance footprint associated with winning natural available clay (Defferrard \& Rohde 2016).

\subsubsection{Capillary break materials}

The CB layer mixture $(+10-30 \mathrm{~mm})$ was the byproduct from crushing and screening the RPL mixture.

\subsubsection{Rock mulch}

The rock mulch was sourced from natural ridge material (siltstone, sandstone and shale) from the adjacent Termite ranges.

\subsection{Construction}

Construction of the three cover trials was completed over a four month period in late 2013 using 16 pieces of equipment including $14 \mathrm{t}$ grader, D8 dozer, pad foot roller, smooth drum roller, cone crusher, jaw crusher, pug mill, $20 \mathrm{t}$ loader and (4) excavators (20,30, 40, 65, and $85 \mathrm{t}$ ). The cover trials were constructed directly on the upper beach of the then-operational TSF approximately $300 \mathrm{~m}$ from the tailing's outfall (Figure 3(b)). This was made possible by constructing a northern embankment and installing a new tailings outfall down gradient of the northern embankment and the cover trials. This created a safe, stable area away from the operational TSF at the time. It would ensure that the cover trials were not compromised by any operational activities and that long-term data could be collected.

The first stage of the trial construction was to prepare the tailings beach over which the cover trial was to be constructed. This was achieved using a grader to fill in the tailings erosion gullies and create a consistent $1 \%$ grade (Figure $3(\mathrm{a})$ ).

Next the trial cell embankment foundation keys were excavated $0.3 \mathrm{~m}$ into the tailings using an excavator while at the same time the lysimeters were installed into the tailings $0.1 \mathrm{~m}$ below the tailing.

The cell embankments were raised with approximately $0.2 \mathrm{~m}$ compacted lifts with moisture conditioned material borrowed from an identified clay deposit from the adjacent Termite ranges (Figure 3(b)). 
Both RPL $(-10 \mathrm{~mm})$ and $\mathrm{CB}(+10-30 \mathrm{~mm})$ mixtures were manufactured using a crushing and screening plant from material won from the adjacent Termite range with dozers and excavators.

The CB was placed in a $0.3 \mathrm{~m}$ thick layer over the tailings using an excavator fitted with a GPS grade control system to ensure quality control requirements were achieved (Figure 3(c)).

Next a $0.3 \mathrm{~m}$ thick rock mulch layer was placed and compacted over the lower CB layer (Figure 3(d)). The RPL was then constructed in $0.2 \mathrm{~m}$ compacted lifts with moisture conditioning achieved with the pug mill; falling head tests were conducted on each lift. The average in situ saturated $\mathrm{K}_{\text {sat }}$ for RPL1 and RPL2 was $2.0 \times 10^{-9} \mathrm{~m} / \mathrm{s}$ and $8 \times 10^{-9} \mathrm{~m} / \mathrm{s}$ respectively.

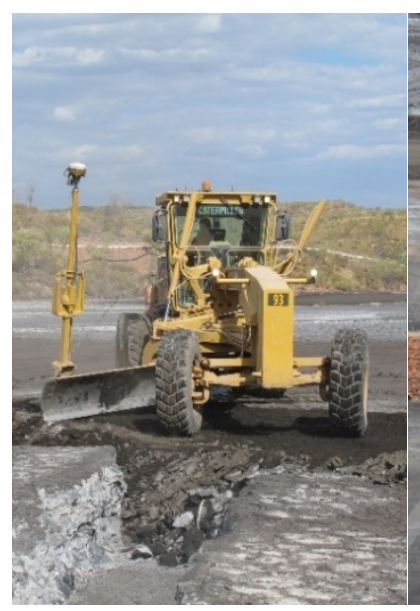

(a)

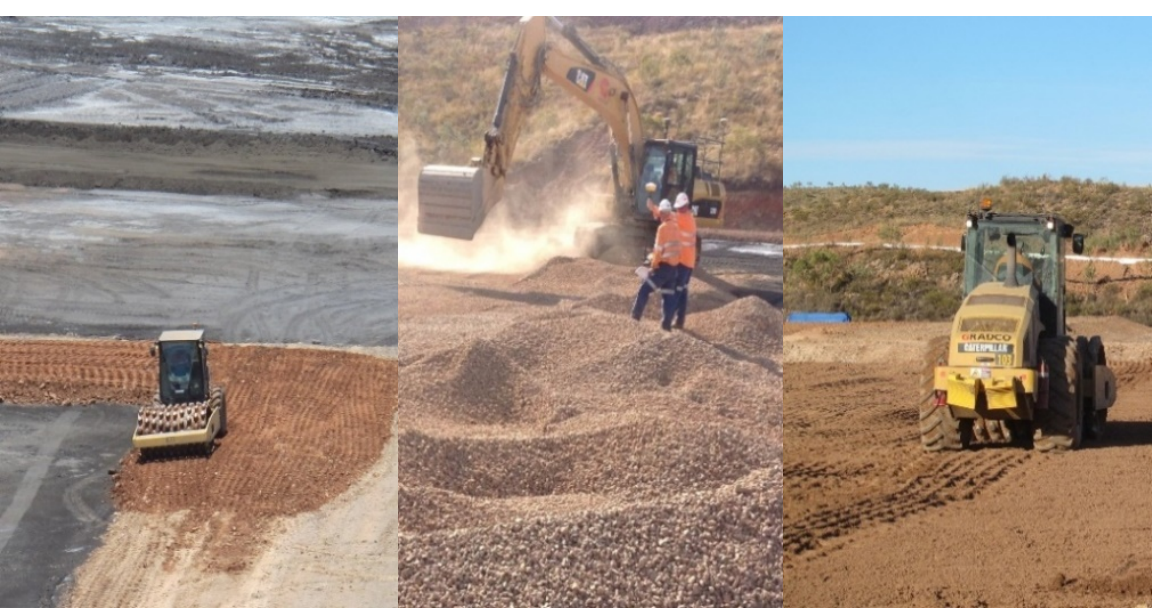

(c)

(d)

Figure 3 (a) Tailings beach preparation; (b) embankment construction; (c) capillary break placement; and, (d) reduced permeability layer (RPL) compaction (Defferrard \& Rohde 2016)

RPL3 was constructed by placing a $0.3 \mathrm{~m}$ thick layer of minus $10 \mathrm{~mm}$ mixture with a maximum of $20 \%$ fines and rolled flat with a smooth drum roller. The RPL mixture was not moisture conditioned and compacted as this trial cell was designed to trial the performance of the geosynthetic clay liner (GCL). Furthermore, the site water contains high cations levels which could have a detrimental effect on the $\mathrm{K}_{\text {sat }}$ through cation exchange. It was proposed to allow for hydration from incident rainfall therefore installed just prior to the wet season. The GCL was rolled out over the entire cell and glued together with a bentonite powder. To complete RPL3 another $0.3 \mathrm{~m}$ thick layer of minus $10 \mathrm{~mm}$ screened mixture was placed over the GCL to bring the RPL up to a $0.6 \mathrm{~m}$ thickness.

To manage the lateral movement of water along the $1 \%$ grade of the RPL a continuous length of $100 \mathrm{~mm}$ agricultural drainage pipe (fitted with a filter sock) was installed in a trench excavated through the cell embankments to enable free drainage outside of the cover trial.

Rock mulch was then loosely placed to a nominal thickness of $1.5 \mathrm{~m}$ over the RPL's to finish the surface with a hummocky profile.

Finally, the hummocky surface was seeded with a tree shrub and grass mix that was representative of the surrounding vegetation.

\subsection{Instrumentation}

\subsubsection{Weather station}

The cover trial monitoring program includes an automated weather station that measures:

- Daily rainfall.

- Maximum wind gust and average wind speed.

- Maximum and minimum air temperature. 
- Maximum and minimum relative humidity.

- Solar radiation.

"The listed parameters are used to calculate the potential evapotranspiration rate using the Penman-Monteith method (Campbell Scientific Inc. 2000)" (Defferrard \& Rohde 2016, p. 9).

\subsubsection{Cover trial sensors}

Defferrard \& Rohde $(2016$, p. 9) stated that "each of the three cover trials were instrumented with a preassembled instrument tree that contained two sensor types:

- Volumetric water content (VWC) sensors using time domain reflectometer.

- Matric suction $(\psi)$ sensors.

Each of the cover system layers contained both a matric suction and VWC sensor. The tailing only contained a matric suction sensor".

\subsubsection{Lysimeters}

The lysimeters were custom made with reinforced $10 \mathrm{~mm}$ high density polyethylene to provide structural strength that can withstand a potentially low $\mathrm{pH}$ environment. The conical drain point of the lysimeter was recessed $500 \mathrm{~mm}$ from the base to allow for considerably easier installation of the lysimeter sump, because it exited on the sidewall (Figure 4(a)). The internal diameter of the lysimeter was $2 \mathrm{~m}$ and the vertical height to the drain point was $1.95 \mathrm{~m}$.

A filter was installed in the base of the lysimeter consisting of a $0.5 \mathrm{~m}$ layer of washed river gravelly sand overlaying a sheet of $3 \mathrm{~mm}$ geofabric. The sand filter and geofabric were installed to prevent the clogging of the sump from silt and clay sized particles migrating from the tailings (Figure 4(b)).

An excavated pit was dug at the centre point of each of the three cover trial cells to accommodate the dimensions of the lysimeter so that the top of the lysimeter rested $0.1 \mathrm{~m}$ below the $1 \%$ graded tailings beach.

The invert level of the pit was confirmed as per design using the GPS grade control system before the lysimeter was lowered into place with an excavator. The tailings around the sump were backfilled by hand (Figure 4(a)).

The excavated pit surrounding the lysimeter was backfilled to a depth of one meter and compacted using whacker-packers (Figure 4(d)).

The lysimeter was backfilled to a depth of $0.5 \mathrm{~m}$ using washed filter sand (Figure 4(b)). The internal area of the lysimeter was backfilled to a depth of one meter and compacted using a whacker-packer (Figure 4(c)).

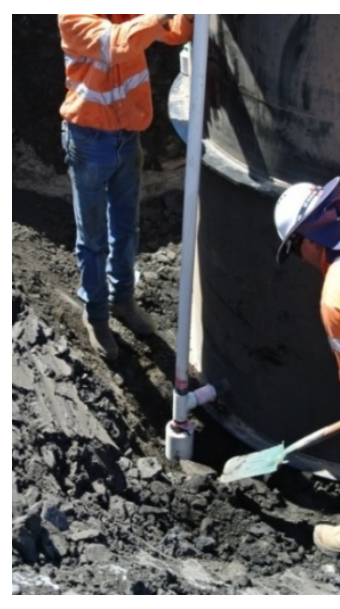

(a)

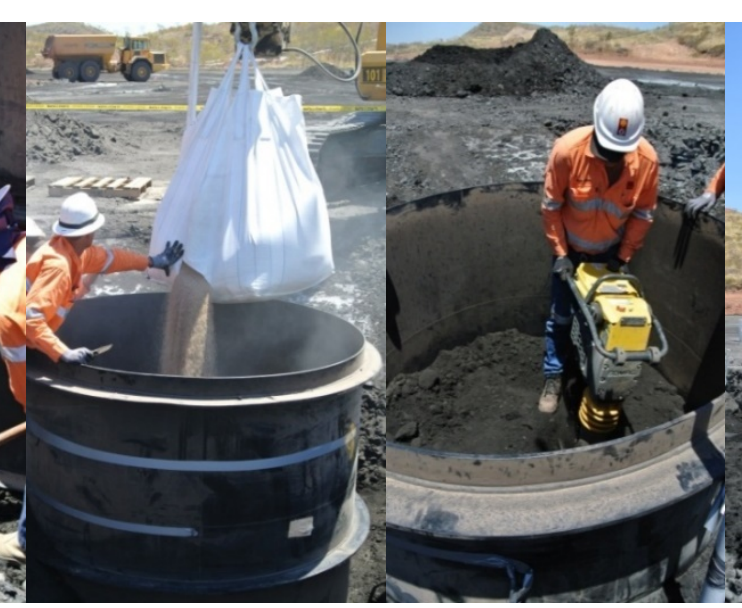

(b) (c)

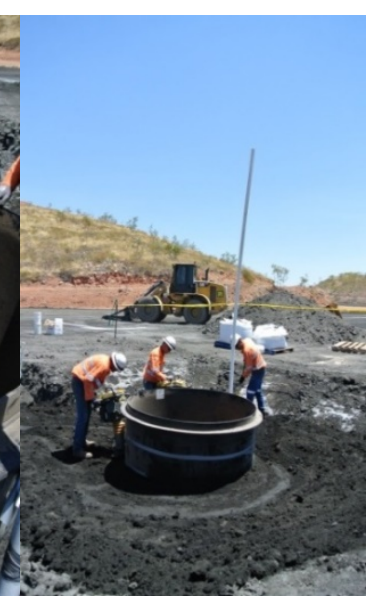

(d)

Figure 4 (a) Placement of lysimeter and sump beneath tailings; (b) backfilling of filter sand in base of lysimeter; (c) internal compacted tailing backfill; (d) external compacted tailing backfill 
The lysimeters require manual purging so that seepage through the cover trials can be measured. The lysimeters are purged by in situ pumps driven by a 12 volt battery from the surface.

\section{$4 \quad$ Results}

\subsection{Rainfall}

Cumulative total rainfall for the monitoring period (January 2014 to February 2019) was 2,545 mm. Figure 5 presents the (5) wet season totals of $467 \mathrm{~mm}$ (January 2014 to October 2014), $273 \mathrm{~mm}$ (November 2014 to October 2015), $723 \mathrm{~mm}$ (November 2015 to October 2016), $557 \mathrm{~mm}$ (November 2016 to October 2017) and $524 \mathrm{~mm}$ (November 2017 to February 2019). Therefore, the trials experienced below average wet season rainfall in 2013/14 and 2014/15, 33 \% above average for 2015/16 and more or less average rainfall for $2016 / 17$ and $2017 / 18$ wet seasons.

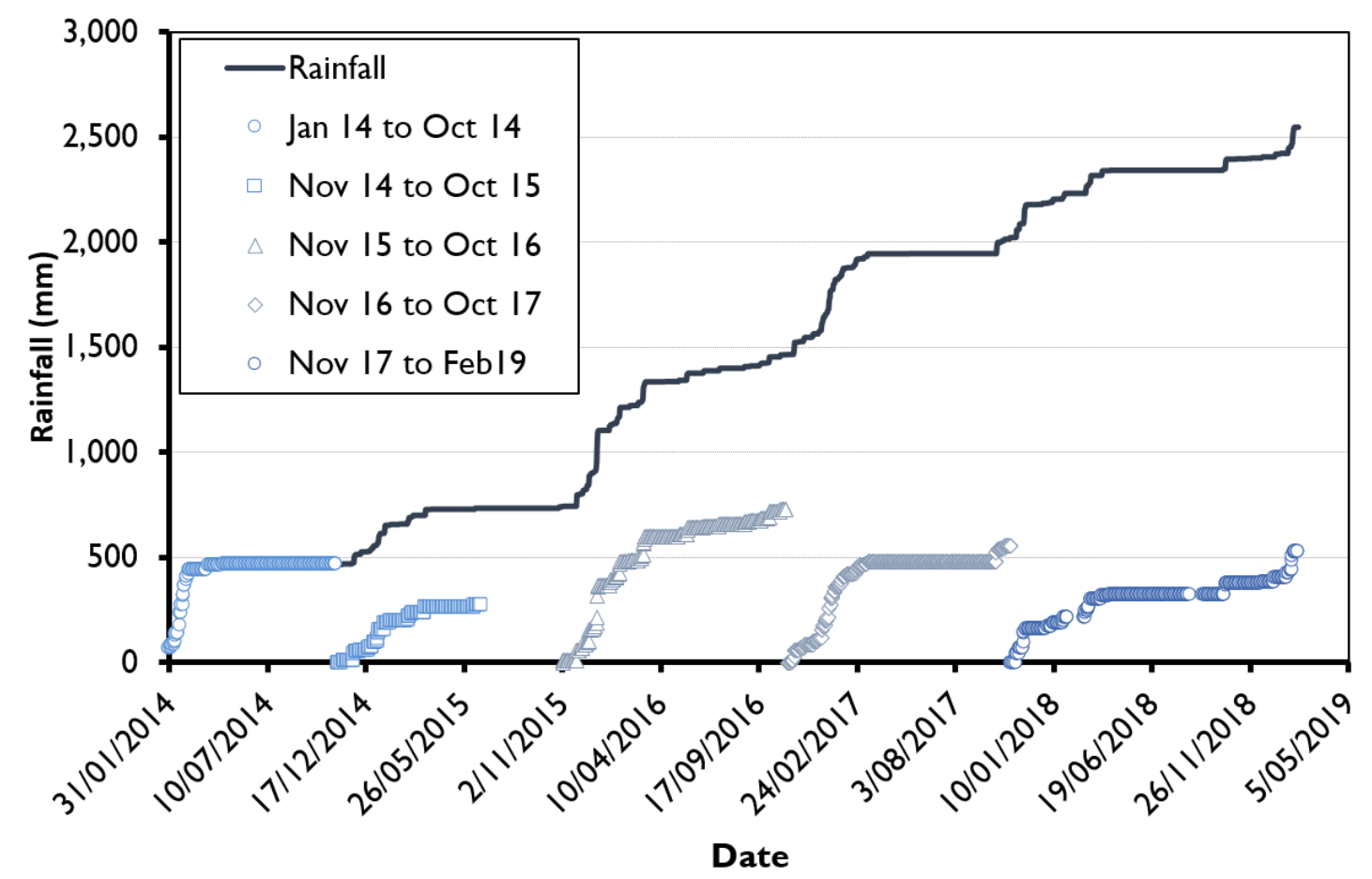

Figure 5 Cumulative rainfall over the total monitoring period as well as the (5) separate annual wet season cumulative rainfall totals

\subsection{Seepage}

The seepage collected in the lysimeter sump for RPL1 in 2014 was $0.2 \mathrm{~L}$, which is $0.06 \mathrm{~mm}$ of cumulative rainfall for that year (Table 1). Dissolved metal concentrations of zinc ( $\mathrm{Zn})$, cadmium (Cd) and manganese $(\mathrm{Mn})$ were detected in the RPL1 lysimeter sump seepage water. Cadmium was below $0.0005 \mathrm{mg} / \mathrm{L}$ and concentrations of $\mathrm{Zn}$ and $\mathrm{Mn}$ were $0.009 \mathrm{mg} / \mathrm{L}$ and $6.147 \mathrm{mg} / \mathrm{L}$, respectively (Table 1 ). The electrical conductivity (EC) was $0.625 \mathrm{mS} / \mathrm{cm}$ and $\mathrm{pH} 7.35$ in RPL1.

Seepage within the RPL2 lysimeter was not detected (Table 1).

RPL3 had collected $1.2 \mathrm{~L}$ of seepage following the 2014 wet season, which equates to $0.38 \mathrm{~mm}$ of rainfall. Lysimeter sump seepage from RPL3 had dissolved metal concentrations of $815 \mathrm{mg} / \mathrm{L} \mathrm{Zn}$ and $0.009 \mathrm{mg} / \mathrm{L} \mathrm{Cd}$. Manganese was below the level of detection (Table 1). The EC was $5.12 \mathrm{mS} / \mathrm{cm}$ and pH 6.03 in RPL3. 
Table 1 Lysimeter sump data for 2014

\begin{tabular}{llllllll}
\hline 2014 & Volume (L) & $\begin{array}{l}\text { Rainfall } \\
\text { (mm) }\end{array}$ & EC (mS/cm) & pH & $\begin{array}{l}\text { Dissolved Zn } \\
\text { (mg/L) }\end{array}$ & $\begin{array}{l}\text { Dissolved Cd } \\
\text { (mg/L) }\end{array}$ & $\begin{array}{l}\text { Dissolved Mn } \\
\text { (mg/L) }\end{array}$ \\
\hline RPL1 & 0.2 & 0.06 & 0.625 & 7.35 & 0.009 & $<0.0005$ & 6.147 \\
RPL2 & $\mathrm{n} / \mathrm{a}$ & $\mathrm{n} / \mathrm{a}$ & $\mathrm{n} / \mathrm{a}$ & $\mathrm{n} / \mathrm{a}$ & $\mathrm{n} / \mathrm{a}$ & $\mathrm{n} / \mathrm{a}$ & $\mathrm{n} / \mathrm{a}$ \\
$\mathrm{RPL3}$ & 1.2 & 0.38 & 5.12 & 6.03 & 815 & 0.009 & $<0.001$ \\
\hline
\end{tabular}

${ }_{1}^{1}$ Seepage volume converted to rainfall $(\mathrm{mm})$ from lysimeter internal base area

No seepage was detected in the 2015 wet season and sampling was not undertaken in 2016.

In 2017 there was no seepage collected in the lysimeter sump for RPL1 (Table 2).

In 2017 RPL2 had $15 \mathrm{~L}$ of seepage which was equivalent to $4.77 \mathrm{~mm}$ of rainfall. Dissolved metal concentrations of $\mathrm{Zn}(10,722 \mathrm{mg} / \mathrm{L}), \mathrm{Cd}(0.12 \mathrm{mg} / \mathrm{L})$ and $\mathrm{Mn}$ was below the level of detection. The EC was $35.7 \mathrm{mS} / \mathrm{cm}$ and $\mathrm{pH} 3.31$.

Seepage within RPL3 lysimeter in 2017 was 333 Litres which was equivalent to $106 \mathrm{~mm}$ of rainfall (Table 2). Lysimeter sump seepage from RPL3 had dissolved metal concentrations of the order of 11,333 mg/L Zn and $0.15 \mathrm{mg} / \mathrm{L} \mathrm{Cd}$ and $3600 \mathrm{mg} / \mathrm{L} \mathrm{Mn}$ (Table 2). Seepage $\mathrm{pH}$ was acidic ranging from 3.31 to 4.7 and EC was high ranging from 29.8 to 35.7 (Table 2).

Table 2 Lysimeter sump data for 2017

\begin{tabular}{llllllll}
\hline 2017 & Volume (L) & $\begin{array}{l}\text { Rainfall } \\
(\mathbf{m m})\end{array}$ & $\begin{array}{l}\mathrm{EC} \\
(\mathbf{m S} / \mathbf{c m})\end{array}$ & $\mathbf{p H}$ & $\begin{array}{l}\text { Dissolved Zn } \\
(\mathbf{m g} / \mathbf{L})\end{array}$ & $\begin{array}{l}\text { Dissolved Cd } \\
(\mathbf{m g} / \mathrm{L})\end{array}$ & $\begin{array}{l}\text { Dissolved Mn } \\
(\mathbf{m g} / \mathbf{L})\end{array}$ \\
\hline RPL1 & $\mathrm{n} / \mathrm{a}$ & $\mathrm{n} / \mathrm{a}$ & $\mathrm{n} / \mathrm{a}$ & $\mathrm{n} / \mathrm{a}$ & $\mathrm{n} / \mathrm{a}$ & $\mathrm{n} / \mathrm{a}$ & $\mathrm{n} / \mathrm{a}$ \\
$\mathrm{RPL2}$ & 15 & 4.77 & 35.7 & 3.31 & 10,722 & 0.12 & $<0.001$ \\
$\mathrm{RPL3}$ & 333 & 106 & 29.8 & 4.7 & 11,333 & 0.15 & 3600 \\
\hline
\end{tabular}

${ }^{1}$ Seepage volume converted to rainfall $(\mathrm{mm})$ from lysimeter internal base area

In 2018 there was no seepage collected in the lysimeter sump for RPL1 (Table 3).

RPL2 had $1 \mathrm{~L}$ of seepage which was equivalent to $0.3 \mathrm{~mm}$ of rainfall. Dissolved metal concentrations were $\mathrm{Zn}$ $(21,000 \mathrm{mg} / \mathrm{L}), \mathrm{Cd}(0.19 \mathrm{mg} / \mathrm{L})$ and $\mathrm{Mn}(4900 \mathrm{mg} / \mathrm{L})$. The $\mathrm{EC}$ was $38 \mathrm{mS} / \mathrm{cm}$ and $\mathrm{pH} 3.48$.

Seepage within RPL3 lysimeter was 7 Litres which was $2.23 \mathrm{~mm}$ of rainfall (Table 3). Lysimeter sump seepage from RPL3 had dissolved metal concentrations of the order of $11,500 \mathrm{mg} / \mathrm{L} \mathrm{Zn}$ and $0.12 \mathrm{mg} / \mathrm{L} \mathrm{Cd}$ and $4050 \mathrm{mg} / \mathrm{L}$ Mn (Table 3).

Table 3 Lysimeter sump data for 2018

\begin{tabular}{llllllll}
\hline 2018 & Volume (L) & $\begin{array}{l}\text { Rainfall }^{1} \\
(\mathbf{m m})\end{array}$ & $\begin{array}{l}\text { EC } \\
(\mathbf{m S} / \mathbf{c m})\end{array}$ & $\mathbf{p H}$ & $\begin{array}{l}\text { Dissolved Zn } \\
(\mathbf{m g} / \mathbf{L})\end{array}$ & $\begin{array}{l}\text { Dissolved Cd } \\
(\mathbf{m g} / \mathrm{L})\end{array}$ & $\begin{array}{l}\text { Dissolved Mn } \\
(\mathbf{m g} / \mathbf{L})\end{array}$ \\
\hline RPL1 & $\mathrm{n} / \mathrm{a}$ & $\mathrm{n} / \mathrm{a}$ & $\mathrm{n} / \mathrm{a}$ & $\mathrm{n} / \mathrm{a}$ & $\mathrm{n} / \mathrm{a}$ & $\mathrm{n} / \mathrm{a}$ & $\mathrm{n} / \mathrm{a}$ \\
$\mathrm{RPL2}$ & 1 & 0.3 & 38 & 3.48 & 21,000 & 0.19 & 4900 \\
$\mathrm{RPL3}$ & 7 & 2.23 & 26 & 3.92 & 11,500 & 0.12 & 4050 \\
\hline
\end{tabular}

${ }^{1}$ Seepage volume converted to rainfall $(\mathrm{mm})$ from lysimeter internal base area

Figure 6 presents the inferred percentage of cumulative rainfall and measured seepage over time from the lysimeter for RPL1, RPL2 and RPL3. 


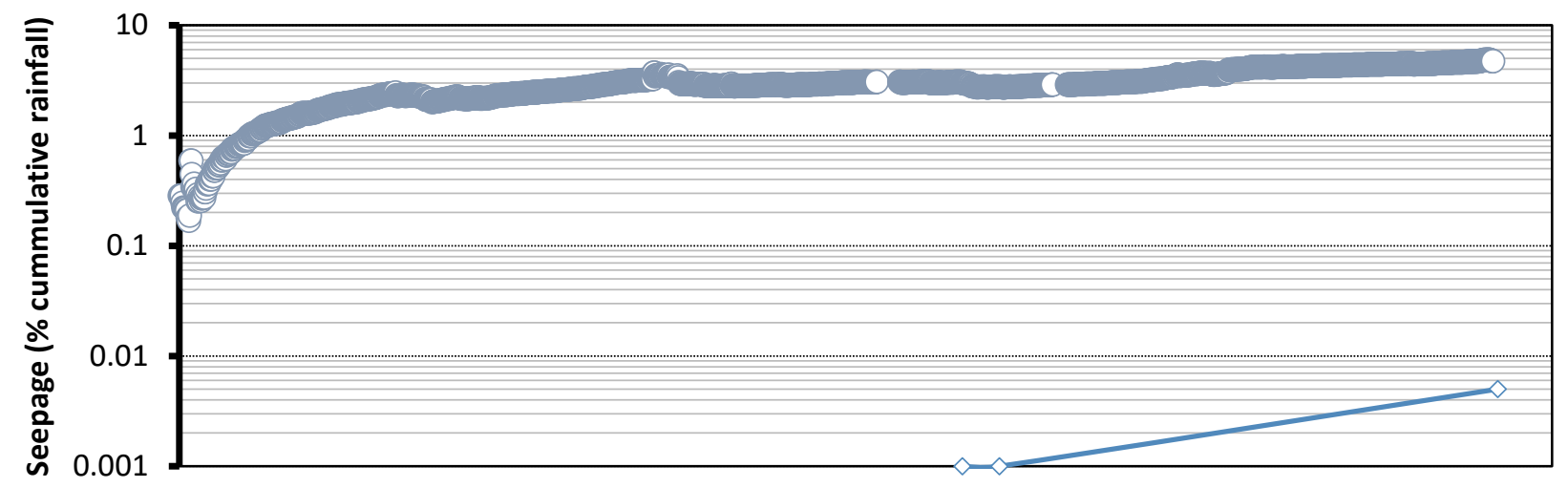

(a)

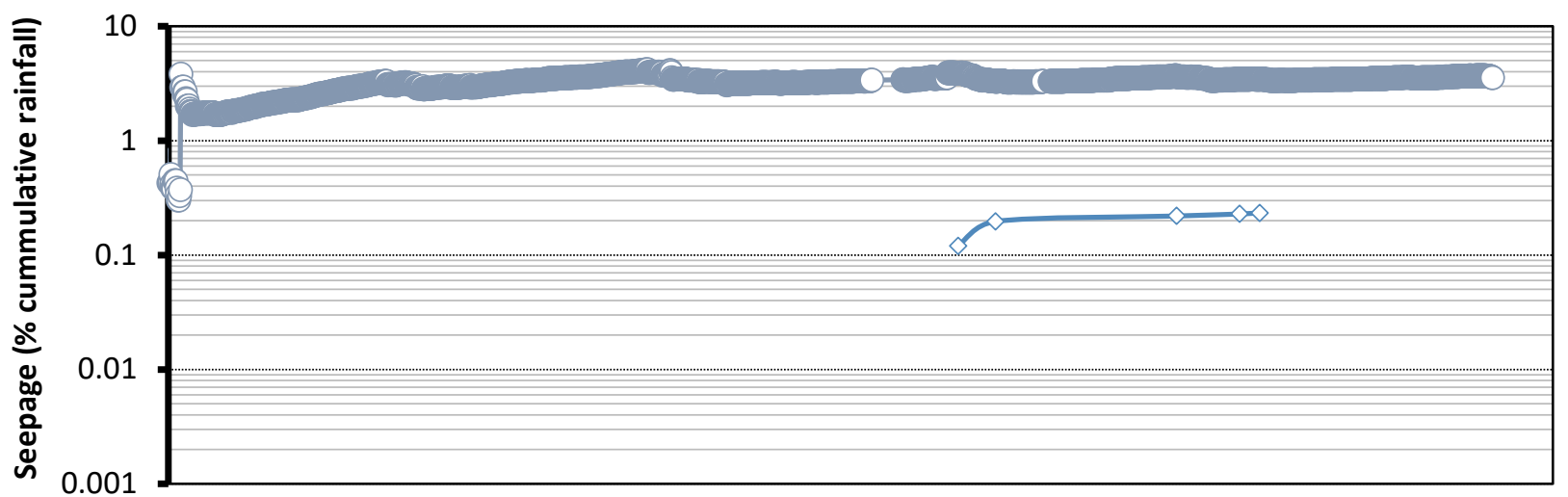

(b)

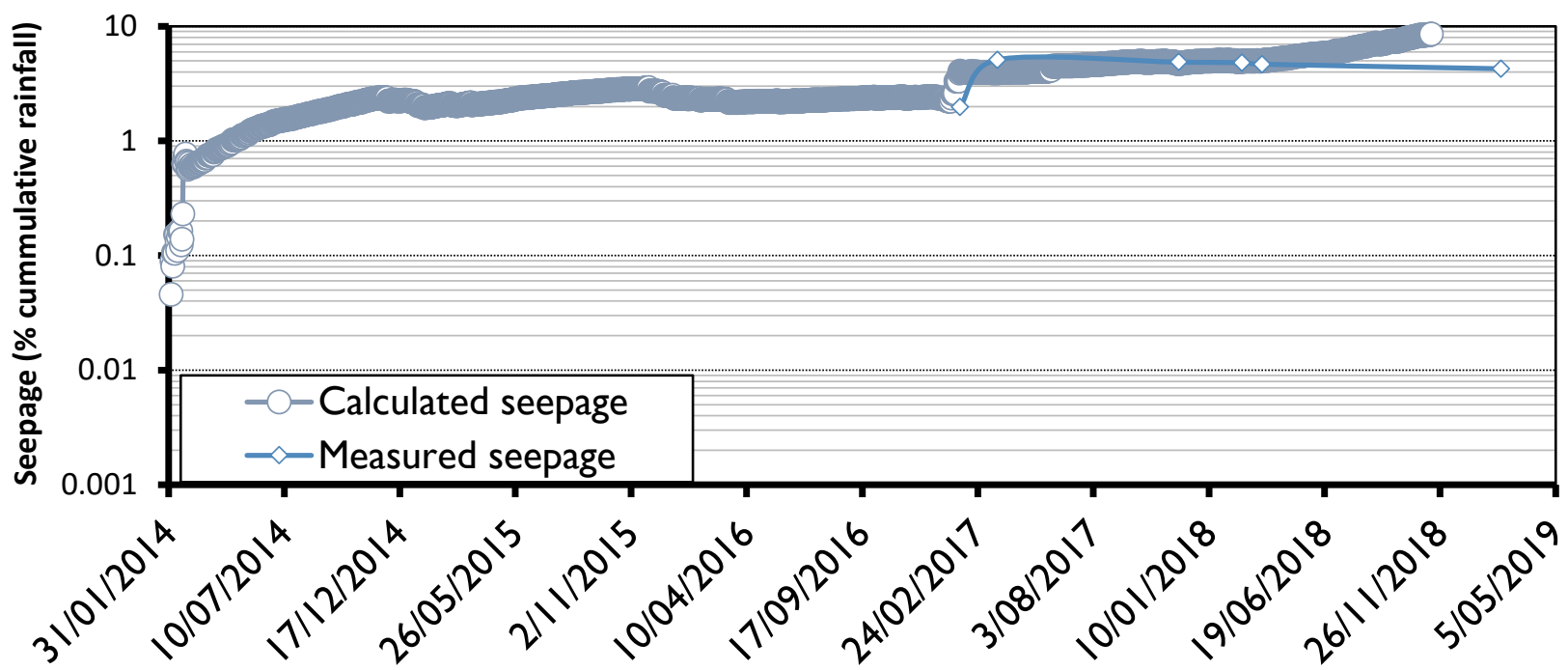

(c)

Figure 6 (a) RPL1 cumulative seepage and measured seepage over time; (b) RPL2 cumulative seepage and measured seepage over time; (c) RPL3 cumulative seepage and measured seepage over time 


\subsection{Electrical conductivity}

Figure 7 presents the electrical conductivity (EC) over time for RPL1, RPL2 and RPL3.

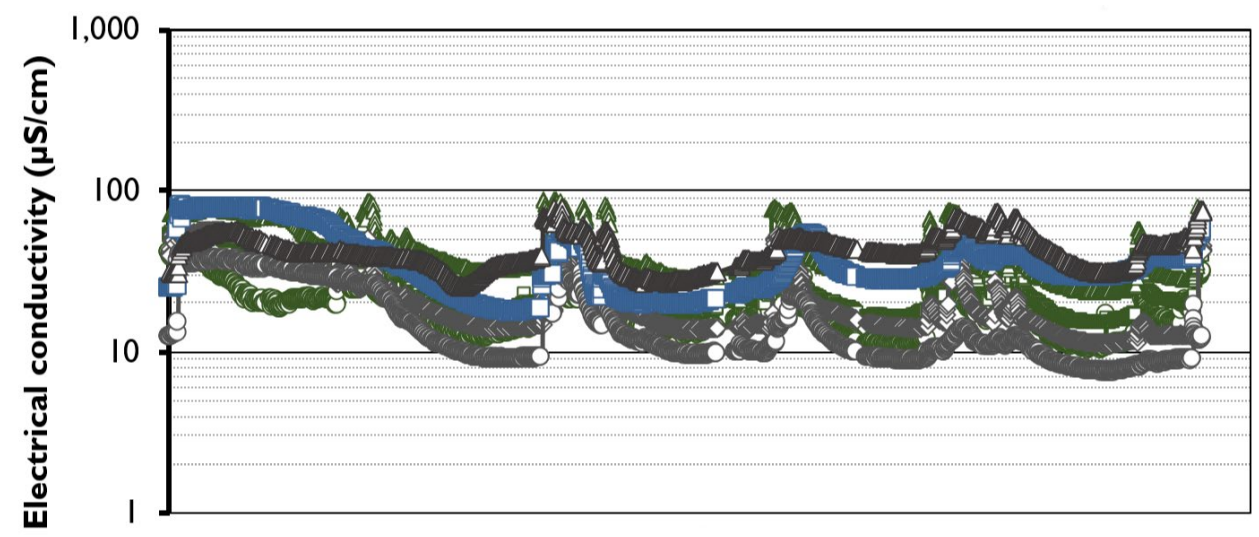

(a)

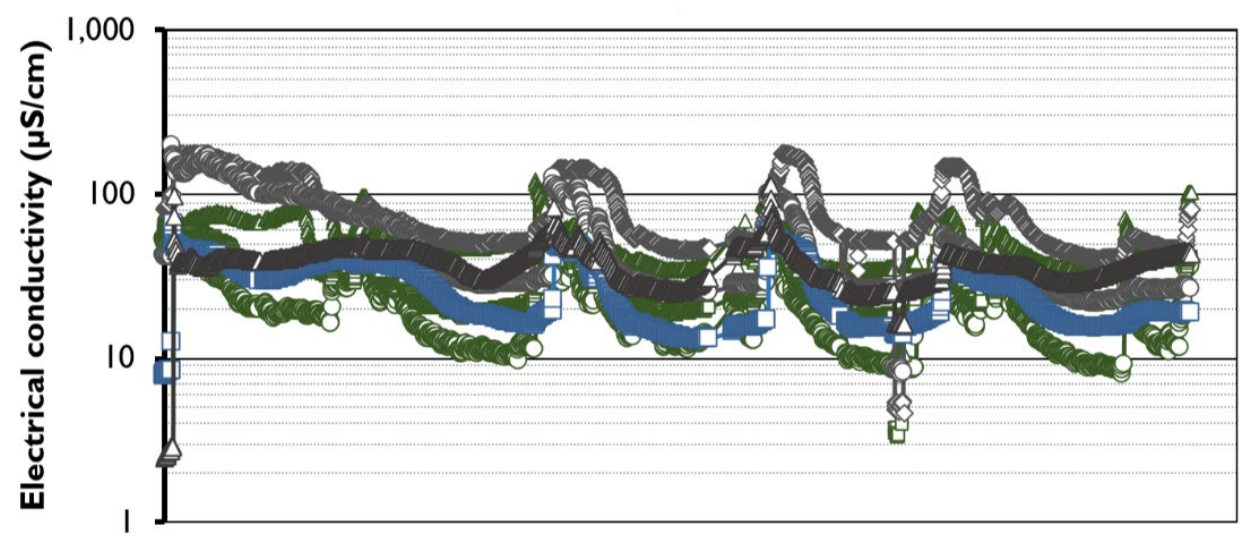

(b)

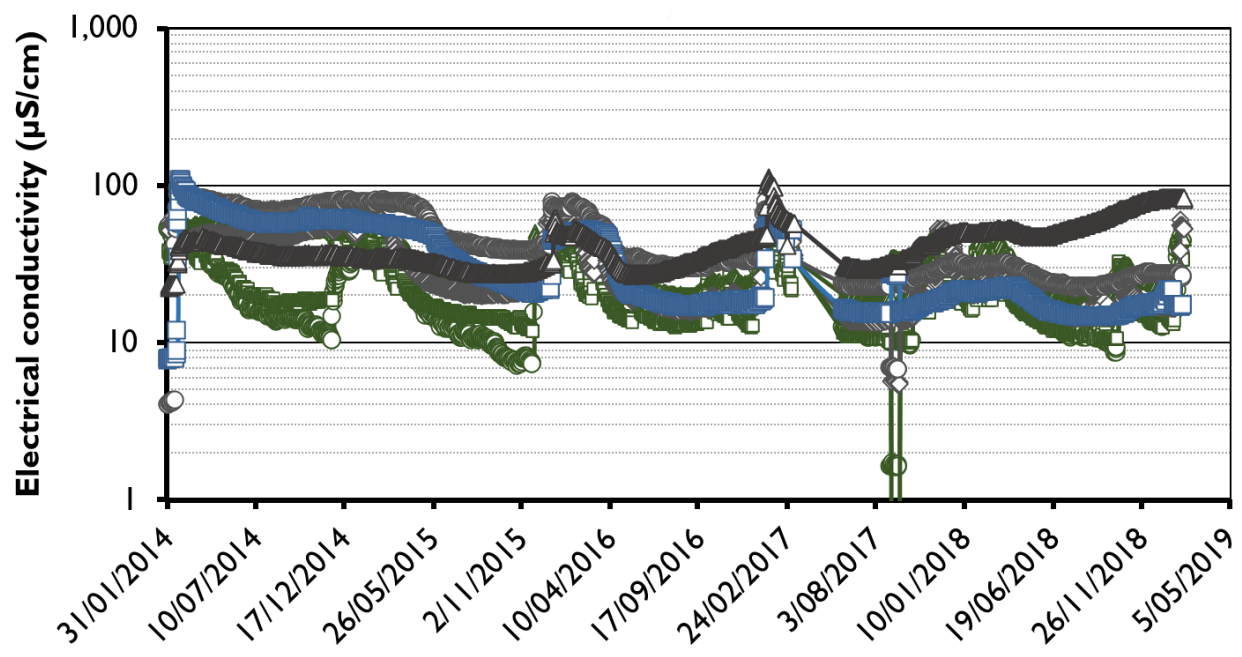

(c)

Figure 7 (a) RPL1 EC over time; (b) RPL2 EC over time; (c) RPL3 EC over time 


\section{Discussion}

\section{$5.1 \quad$ Seepage}

The calculated seepage expressed as a percentage of cumulative rainfall following the six years of monitoring for RPL1, RPL2 and RPL3 is 4.7, 3.5, and $8.5 \%$, respectively. Measured seepage as a percentage of cumulative rainfall for RPL1, RPL2 and RPL3 was $0.01,0.23$, and $4.26 \%$, respectively, following the 6 years of monitoring. It is understood these calculated/inferred seepages are expected to be higher than the measured lysimeter seepage as there is a storage component within the tailings and the seepage data is derived from the VWC sensor in the CB (Defferrard \& Rohde 2016). The measured and calculated seepage results for RPL3 are the only results that correlate (Figure 6(c)). This could potentially be attributed to RPL3 consisting of a multi joined GCL system and not a single fully compacted $0.6 \mathrm{~m}$ RPL layer like RPL1 and RPL2.

\subsection{Electrical conductivity}

The EC in all (3) cover profiles for RPL1, RPL2 and RPL3 are within the range $6 \mu \mathrm{S} / \mathrm{cm}$ to $200 \mu \mathrm{S} / \mathrm{cm}$, which demonstrates that there is no capillary rise of salts into the cover. Increases in EC in all (3) covers coincide with the wet season rainfall infiltration only to decrease back down to a horizontal baseline trend during the dry season (Figure 7).

\section{Conclusion}

NCR Century Mine has designed instrumented and constructed a large-scale TSF cover trial through a robust process that accounts for climate, hydrology, human activities, vegetation, settlement and constructability. The cover profile for each trial was $2.7 \mathrm{~m}$ in thickness including $0.3 \mathrm{~m}$ CB layer, $0.3 \mathrm{~m}$ compacted running layer, $0.6 \mathrm{~m} \mathrm{RPL}$ and $1.5 \mathrm{~m}$ rock mulch layer. The RPL was the only aspect of each trial that differed. RPL1 was constructed from $-10 \mathrm{~mm}$ cracker dust material containing $30 \%$ fines, RPL2 with $-10 \mathrm{~mm}$ cracker dust material containing $10 \%$ dry weight bentonite and fines in the range $15 \%$ to $30 \%$ and finally RPL3 was a GCL sandwiched between uncompacted $-10 \mathrm{~mm}$ cracker dust.

The cover trials over the monitoring period have experienced below average, average and above average rainfall events which have enabled the cover to be monitored in response to a number of wetting and drying cycles. Cover trials RPL1 and RPL2 to date have performed the best with calculated seepage (\% cumulative rainfall) at $4.7 \%$ and $3.5 \%$ respectively. RPL3 with seepage of $8.5 \%$ is still considered to be acceptable, with the industry minimum standard of $\leq 10 \%$ (Defferrard et al. 2015).

Six years of EC monitoring through the cover profile have provide valuable performance data of the $\mathrm{CB}$ and the cover design as a whole as the EC levels have remained within an acceptable range confirming that capillary rise of salts from the tailings is not occurring.

Even though an engineered cover option will not form the main TSF closure strategy at Century Mine, the performance data obtained from the cover trials will provide insightful information to select a robust cover design in the event any residual tailings need to be encapsulation.

\section{References}

Campbell Scientific Inc. 2000, On-Line Estimation of Grass Reference Evapotranspiration with the Campbell Scientific Automated Weather Station, https://s.campbellsci.com/documents/us/technical-papers/evap.pdf

Buckley J, Gates, WP, Gibbs D \& Gassner F 2010, 'Forensic examination of field GCL performance in landfill capping and mining containment applications', Proceeding of 3rd International Symposium on Geosynthetic Clay Liners, Wursburg.

Dames \& Moore 1994, The Century Project: Draft Impact Assessment Study Report, vol 3, Century Zinc, Spring Hill.

Defferrard, PL \& Rohde, TK 2016, 'Leading practice store and release cover trials for a tailings storage facility at Century Mine', Proceedings of 11th Australian Acid and Metalliferous Drainage Conference, Perth, Australian Centre for Geomechanics, Western Australia. 
Defferrard, PL, Rohde, TK \& Lord M 2015, 'Instrumentation and early monitoring results of the South Waste Rock Dump at Century mine', in AB Fourie, M Tibbett, L Swatsky \& D van Zyl (eds), Proceedings of the 10th International Conference on Mine Closure, InfoMine, Vancouver, pp. 917-928.

Defferrard, PL, Rohde, TK \& Milsom, BJ 2014, 'Performance of a cover on a bulk sample tailings dam at Century Mine', Proceedings of 8th Australian Acid and Metalliferrous Drainage Conference, Adelaide, JKTech Pty Ltd, Queensland.

Department of Industry Tourism and Resources 2007, Managing Acid and Metalliferous Drainage, Commonwealth of Australia, https://www.im4dc.org/wp-content/uploads/2014/01/Managing-acid-and-metalliferous-drainage.pdf International Network for Acid Prevention 2009, Global Acid Rock Drainage Guide. 
